\title{
Analisis Pengaruh Perputaran Piutang Terhadap Return On Investment Pada PT Telekomunikasi PerseroTbk.
}

\author{
Hartanti \\ Universitas Bina sarana Informatika \\ hartanti.hti@bsi.ac.id

\section{Ratiyah} \\ Universitas Bina Sarana Informatika \\ ratiyah.rty@bsi.ac.id

\section{Pingkan morrend aniky} \\ Universitas Bina Sarana Informatika \\ pingkanmorrendaniky@gmail.com
}

\begin{abstract}
Abstrak Perusahaan dalam menjalankan usahanya pasti memerlukan modal kerja, modal kerja salah satunya berasal dari piutang, modal kerja yang digunakan oleh perusahaan pada akhirnya akan menghasilkan profit kepada perusahaan. Pengujian pengaruh perputaran Piutang terhadap Return On Investment PT Telekomunikasi Persero Tbk merupakan tujuan dari penelitian ini. Metode kuantitatif dengan menggunakan uji statistik yaitu Uji korelasi, koefisien determinasi, uji t dan persamaan Regresi metode yang di gunakan dalam penelitian ini. Data berupa laporan keuangan PT Telkom tahun 2012-2018. Hasil Uji korelasi menunjukkan ada hubungan positif, kuat dan searah antara perputaran Piutang terhadap Return On InvestmentPT Telekomunikasi Persero Tbk. Hasil Uji determinasi menunjukkan pengaruh sebesar 37,7\% dan 62,3\% dipengaruhi faktor yang lain . Uji t menunjukkan ada pengaruh yang signifikan terhadap variabel yang diteliti, sedangkan uji persamaan regresi menunjukkan ada persamaan regresi signifikan yang terbentuk yaitu $\mathrm{Y}=0,386+0,112 \mathrm{X}$

Kata Kunci Perputaran Piutang, Return on investment
\end{abstract}

\section{PENDAHULUAN}

Perusahaan dalam mencapai sebuah tujuannya pasti membutuhkan dana. Baik itu dana untuk kegiatan operasional sehari-hari maupun jangka panjang. Perusahaan harus menyediakan dana tersebut, karena jika terjadi kekurangan dana akan berdampak terhadap keuntungan dan kegagalan didalam pencapaian tujuan perusahaan. Dana yang digunakan dalam operasional sehari-hari disebut dengan modal kerja (working capital).

Perusahaan Telekomunikasi (Persero) Tbk merupakan perusahaan BUMN yang bergerak dalam bidang telekomunikasi, dalam menjalankan pun membutuhkan modal 
kerja. Hasil dari aktivitas atau pendapatan yang diperoleh oleh perusahaan tersebut tidak selalu berupa pembayaran secara tunai tetapi bisa dilakukan secara kredit. Pembayaran secara kredit timbul namanya piutang. Piutang merupakan salah satu komponen dari modal kerja perusahaan. Efektif tidaknya piutang dalam perusahaan dapat diukur dengan melihat berapa kali tingkat perputaran piutang. Kondisi perusahaan akan baik apabila tingkat perputaran piutangnya tinggi dan sebaliknya jika perputaran piutangnya rendah maka perusahaan dalam kondisi tidak baik.

PT Telekomunikasi Persero Tbk pun dalam menjalankan usaha bertujuan melayani kebutuhan masyarakat dalam bidang industri telekomunikasi. PT telekomunikasi Persero Tbk sepanjang tahun 2017 mempunyai kinerja yang cukup memuaskan dibandingkan tahun sebelumnya, dari sisi pendapatan usaha terdapat pertumbuhan sebesar 10,2\% dibanding tahun 2016. Laba bersih naik menjadi 14,4\% dan dari sisi profitabilitas margin bersih naik 17,3\%. Dikuartal 12018 untuk keuntungan dari PT Telekomunikasi sempat mengalami penurunan tetapi dikuartal III tahun 2018 menunjukkan kinerja yang baik salah satunya dari sisi pendapatan tumbuh 8,8\% QoQ dibandingkan kuartal II. Dari sisi profitabilitas naik cukup tinggi dibandingkan kuartal II ditahun yang sama. Untuk menaikkan performa dari kinerja perusahaan, perusahaan menerapkan berbagai strategi agar kinerja perusahaan tetap baik dan salah satunya adalah menaikkan tingkat profit/keuntungan perusahaan. Alat ukur kinerja dari sisi keuntungan/profitabilitas bisa digunakan rasio Return On Investment. Return on Investment (ROI).

Menurut (Santoso, 2013) "yang melakukan penelitian tentang perputaran modal kerja dan pengaruh perputaran piutangnya terhadap profitabilitas pada PT Pengadaian Persero, hasil penelitiannya tersebut salah satunya bahwa perputaran piutang mempunyai pengaruh signifikan terhadap profitabilitas pada PT pengadaian Persero"

Menurut penelitian (Yuliani \& Salim, 2012) "melakukan penelitian tentang pengaruh perputaran piutang terhadap probitabilitas Pada PT Uniliver Indonesia Tbk. Profitabilitasnya menggunakan Return on Asset, dimana hasil penelitiannya terdapat pengaruh signifikan perputaran piutang terhadap profitabilitas"

(Luh Komang Suarnami, 2014) melakukan penelitian "pengaruh perputaran piutang dan periode pengumpulan piutang terhadap probitabilitas pada perusahaan pembiayaan, hasil penelitiannya bahwa perputaran piutang secara parsial tidak berpengaruh positif terhadap profitabilitas."

\section{LANDASAN TEORI}

\section{A. 1. Perputaran Piutang}

Menurut (Harisson, Horngren, Thomas, \& Suwardy, 2012) “piutang adalah klaim moneter terhadap lainnya. Piutang diperoleh terutama dengan menjual barang dan jasa (piutang usaha) serta meminjam uang."

(Manullang \& Sinaga, 2005) mengklasifikasikan piutang sebagai berikut :

1. Piutang usaha 
Piutang usaha merupakan segala tagihan dari penjualan barang-barang atau jasa yang dilakukan secara kredit oleh perusahaan. Jika taguhan itu didukung dengan tagihan tertulis oleh debitur kepada perusahaan untuk membayar pada satu tanggal tertentu, piutang tersebut adalah piutang wesel.

2. Piutang lain-lain

Piutang lain-lain merupakan tagihan yang tidak berasal dari penjualan barang maupun jasa dalam kegiatan norma perusahaan

Menurut (Kasmir, 2013), “yang menyatakan bahwa Perputaran piutang merupakan rasio yang digunakan untuk mengukur beberapa lama penagihan piutang selama satu periode atau beberapa kali dana yang ditanam dalam piutang ini berputar dalam satu periode. Semakain tinggi rasio menunjukan bahwa modal kerja yang ditanam dalam piutang semakin rendah dan tentunya kondisi ini bagi perusahaan semakin baik"

Rumus perputaran piutang sebagai berikut.

$$
\text { perputaranpiutang }=\frac{\text { Penjualan Bersih }}{\text { Rata-Rata Piutang }}[1]
$$

\section{Return On Investment}

Menurut (Munawir, 2007) "yang menyatakan jika ROI itu merupakan bentuk maupun rasio dari profitabilitas yang berguna untuk mengukur kemampuan atau efektifitas dari perusahaan dalam menghasilkan sebuah keuntungan yang berasal dari seluruh dana yang berguna dalam operasional perusahaan".

Menurut (Syamsudin, 2007) "Return oninvestment ini ialah perbandingan antara laba bersih setelah pajak dengan total aktiva".

Adapun rumus yang digunakan dalam menghitung Return on Investment adalah :

$$
\left.R O I=\frac{\text { Laba Bersih Setelah Pajak }}{\text { TotalAktiva }}\right]
$$

\section{METODOLOGI PENELITIAN}

Penelitian ini menggunakan analisis Deskriptif kuantitatif, dimana penulis melakukan penelitian mengenai " Pengaruh Perputaran Piutang terhadap Return On Investment pada PT Telekomunikasi Persero Tbk. Data Penelitian ini menggunakan data Laporan keuangan Neraca dan Laba Rugi Kuartal 1 tahun 2012 sampai dengan kuartal III tahun 2018. Adapunvariabel Indepedent nya perputaran piutang dan variabel dependentnya adalah return on investment. Dalam penelitian ini penulis menggunakan uji hipotesis korelasi, koefisien determinasi, regresi sederhana dan uji t

\section{Uji hipotesis korelasi}

Menurut (Wiratna Sujarweni, 2016) memberikan batasan bahwa “ uji korelasi bertujuan untuk menguji hubungan antra dua variabel dapat dilihat dengan tingkat signifikan, jika ada hubungan maka akan dicari seberapa kuat hubungan tersebut, hubungan kuat atau tidaknya diukur dengan koefisien korelasi." 
Syarat signifikansi dua variabel mempunyai hubungan sebagai berikut:

a) Jika sig $>0,05$ maka Ha diterima artinya terdapat hubungan antar dua variabel

b) Jika sig < 0,05 maka Ha di tolak artinya tidak ada hubungan antar dua variabel Nilai koefisien korelasi merupakan nilai yang digunakan untuk koefisien suatu hubungan antara variabel. Koefisien korelasi memiliki nilai angka (+1) sampai (-1) sifat nilai koefisien korelasi antara plus $(+)$ atau minus (-), maka sifat korelasi :

a) Korelasi positif $(+)$ berarti bahwa jika variabel X1mengalami kenaikan maka variabel X2akan mengalami kenaikan, begitupun sebaliknya.

b) Korelasi negatif (-) berarti bahwa jika variabel X1mengalami penurunan maka variabel X2akan mengalami kenaikan, begitupun sebaliknya.

(Sarwono, 2006) memberikan kriteria sebagai berikut :

Tabel II.1.

\section{Tingkat Hubungan Koefisien Korelasi}

\begin{tabular}{|l|l|}
\hline Interval Koefisien Korelasi & \multicolumn{1}{c|}{ Tingkat Hubungan } \\
\hline \multicolumn{1}{|c|}{0} & Tidak ada korelasi antara dua variabel \\
\hline$>0-0,25$ & Korelasi sangat lemah \\
\hline$>0,25-0,50$ & Korelasi cukup \\
\hline$>0,50-0,75$ & Korelasi Kuat \\
\hline$>0,75-0,99$ & Korelasi sangar kuat \\
\hline 1 & Korelasi Sempurna \\
\hline
\end{tabular}

Sumber: (Sarwono, 2006)

\section{Uji koefisien Determinasi}

Menurut (sugiyono, 2011) menyebutkan bahwa, "dalam analisa korelasi terdapat suatu angka yang disebut koefisien determinasi, yang besarnya adalah kuadrat dari koefisien korelasi $\left(r^{2}\right)$ ".

Dalam (Sarwono, 2006) "koefisien determinasi $\left(\mathrm{R}^{2}\right)$ yang berfungsi untuk mengetahui besarnya proporsi variasi variabel terikat yang dapat dijelaskan dengan variabel bebas ". Jika Hasil koefisien determinasi $\left(\mathrm{R}^{2}\right)$ kecil maka kemapuan variabel bebas sangat terbatas dalam menjelaskan variabel terikat. Tetapi jika hasil mendekati angka 1 maka kemampuan variabel bebas dapat menjelaskan lebih lebih luas/lengkap informasi dalam memprediksi variabel terikat.

\section{Uji Persamaan regresi}

Analisis persamaan regresi sederhana merupakan posisi antarvariabel tidak setara (yang satu merupakan variabel dependent dan lainnya variabel independent).

Persamaan regresi linear sederhana adalah:

$\mathrm{Y}^{\prime}=\mathrm{a}+\mathrm{b} . \mathrm{X}+\mathrm{e}$ 
Keterangan:

$\mathrm{Y}^{\prime}=$ nilai Y prediksi

$\mathrm{a}=$ intercept atau nilai rata-rata $\mathrm{Y}$ prediksi jika $\mathrm{X}=0$

$\mathrm{b}=$ slope atau rata-rata perubahan pada $\mathrm{Y}$ jika $\mathrm{X}$ berubah 1 satuan

$\mathrm{X}=$ variabel bebas

$\mathrm{e}=$ kesalahan prediksi (error)

\section{HASIL PENELITIAN}

1. Uji Koefisien korelasi

Hipotesis yang terbentuk dari hubungan atau korelasi antara Perputaran Piutang dengan return On Investment pada PT Telekomunikasi Persero Tbk, adalah:

Ho : Tidak ada hubungan signifikan antara Perputaran Piutang dengan Return On Investment pada PT Tekomunikasi Persero Tbk.

Ha : Ada hubungan signifikan antara Perputaran Piutang dengan Return On Investment pada PT Tekomunikasi Persero Tbk.

Hasil pengujian koefisien korelasi dengan pengolahan SPSS adalah:

Tabel 2. Koefisien korelasi

\begin{tabular}{|c|c|c|c|}
\hline \multicolumn{4}{|c|}{ Correlations } \\
\hline & & $\bar{x}$ & $\bar{y}$ \\
\hline \multirow[t]{3}{*}{ perputaran piutang } & Pearson Correlation & 1 & $.614^{\pi \pi}$ \\
\hline & Sig. (2-tailed) & & .001 \\
\hline & $N$ & 27 & 27 \\
\hline \multirow[t]{3}{*}{ return on investment } & Pearson Correlation & $.614^{\pi \pi}$ & 1 \\
\hline & Sig. (2-tailed) & .001 & \\
\hline & $N$ & 27 & 27 \\
\hline
\end{tabular}

sumber: hasil olah data

Berdasarkan tabel 2 koefisien korelasi menunjukkan hasil tingkat signifikan sebesar 0,001 . Hasil tersebut dibawah $0,05(0,001<0,05)$, sehingga hasil uji hipotesa yang diterima adalah ha yaitu ada hubungan yang signifikan antara Perputaran Piutang dengan Return On Investment pada PT Tekomunikasi Persero Tbk. Hasil korelasinya sebesar 0,614. Menurut Sarwono (2015) hasil korelasi/hubungan antara kedua variabel ini pada kategori Kuat dan hasilnya positif/searah. Sehingga dapat disimpulkan bahwa terdapat hubungan yang signifikan dan kuat positif /searah antara Perputaran Piutang dengan Return On Investment pada PT Tekomunikasi Persero Tbk. Hubungan ini dapat diartikan jika perputaran piutang naik maka Return On Investmentjuga mengalami kenaikan begitu juga sebaliknya jika perputaran piutangnya rendah maka Return on Investment juga rendah.

2. Uji Koefisien Determinasi 

adalah:

Hasil dari pengolahan dengan Aplikasi SPSS untuk koefisien determinasi

Tabel 3. Koefisien Determinasi

\begin{tabular}{|c|c|c|c|c|c|c|c|c|c|}
\hline \multicolumn{10}{|c|}{ Model Summary } \\
\hline \multirow[b]{2}{*}{ Model } & \multirow[b]{2}{*}{$\mathrm{R}$} & \multirow[b]{2}{*}{ R Square } & \multirow[b]{2}{*}{$\begin{array}{c}\text { Adjusted R } \\
\text { Square }\end{array}$} & \multirow[b]{2}{*}{$\begin{array}{c}\text { Sto. Error of the } \\
\text { Estimate }\end{array}$} & \multicolumn{5}{|c|}{ Change Statistics } \\
\hline & & & & & $\begin{array}{c}\mathrm{R} \\
\text { Square } \\
\text { Chabge }\end{array}$ & $\begin{array}{c}F \\
\text { Change }\end{array}$ & df1 & $\mathrm{Df} 2$ & $\begin{array}{l}\text { Sig.F } \\
\text { Change }\end{array}$ \\
\hline 1 & $.814^{4}$ & 377 & .352 & .36937 & .377 & 15,142 & 1 & 25 & .001 \\
\hline
\end{tabular}

Sumber: hasil olah data

Berdasarkan tabel 3 koefisien determinasi, diperoleh hasil R Square sebesar 0,377. Hal ini menunjukkan bahwa pengaruh variabel independen (perputaran piutang) terhadap variabel dependen (return on investment) sebesar 37,7\% artinya variabel independen (perputaran piutang) hanya mempengaruhi variabel dependen (return on investment) sebesar $37,7 \%$ sedangkan sisanya $62,3 \%$ dipengaruhi oleh faktor lain yang tidak diteliti

\section{Uji Persamaan regresi}

Hipotesis yang terbentuk dari persamaan regresi antara Perputaran Piutang dengan Return On Investment pada penelitian ini adalah:

Ho : Tidak terdapat persamaan regresi antara Perputaran piutang dengan Return On Investment yang signifikan pada PT Telekomunikasi Persero Tbk

$\mathrm{Ha}$ : Terdapat persamaan regresi antara Perputaran piutang dengan Return On Investment yang signifikan pada PT Tekomunikasi Persero Tbk.

Berikut ini adalah hasil pengolahan SPSS untuk persamaan regeresi

Tabel 4. Tabel persamaan regresi

\begin{tabular}{|c|c|c|c|c|c|}
\hline \multicolumn{6}{|c|}{ Coefficients $^{a}$} \\
\hline \multirow[b]{2}{*}{ Model } & \multicolumn{2}{|c|}{ Unstandardized Coefficients } & \multirow{2}{*}{$\begin{array}{c}\begin{array}{c}\text { Standardized } \\
\text { Coefficients }\end{array} \\
\text { Beta }\end{array}$} & \multirow[b]{2}{*}{ t } & \multirow[b]{2}{*}{ Sig. } \\
\hline & $B$ & Std. Error & & & \\
\hline (Constant) & .386 & .174 & & 2.224 & .035 \\
\hline perputaran piutang & .112 & .029 & .614 & 3.891 & .001 \\
\hline
\end{tabular}

Sumber: Hasil olah data

Berdasarkan tabel 4. Pengujian hipotesa untuk persamaan regresi signifikansi menunjukkan $0,001(0,001<0,05)$ sehingga hasilnya Ha diterima. Hal ini berarti terdapat 
persamaan regresi antara Perputaran Piutang dengan Return On Investment pada PT Tekomunikasi Persero Tbk. Adapun persamaan regresi yang terbentuk adalah:

$$
\mathrm{Y}=0,386+0,112 \mathrm{X}
$$

Dari persamaan regresi tersebut, dapat diketahui bahwa koefisien intercept (a) dari persamaan diatas adalah sebesar 0,386 artinya jika tidak ada perputaran kas (X), maka nilai perolehan return on investment (Y) adalah sebesar 0,386. Dari persamaan diatas juga, dapat dilihat bahwa koefisien slope (b) atau kemiringan dari regresi adalah sebesar 0,112 artinya bahwa setiap penambahan $1 \%$ tingkat perputaran piutang, maka return on investment akan mengalami kenaikan sebesar $0,112 \%$

\section{Uji t}

Hipotesis untuk menggambarkan pengaruh antaraPerputaran Piutang dengan Return On Investment pada PT Tekomunikasi Persero Tbk, adalah

Ho : Tidak terdapat pengaruh antara perputaran piutang dengan Return On Investment yang signifikan pada PT Tekomunikasi Persero Tbk.

$\mathrm{Ha}$ : Terdapat pengaruh antara perputaran piutang dengan Return On Investment yang Signifikan pada PT Tekomunikasi Persero Tbk.

Tabel 6. Tabel uji t

\begin{tabular}{|c|c|c|c|c|c|c|}
\hline \multicolumn{7}{|c|}{ Coefficients $^{a}$} \\
\hline \multirow{2}{*}{\multicolumn{2}{|c|}{ Model }} & \multicolumn{2}{|c|}{ Unstandardized Coefficients } & \multirow{2}{*}{$\begin{array}{c}\begin{array}{c}\text { Standardized } \\
\text { Coefficients }\end{array} \\
\text { Beta }\end{array}$} & \multirow[b]{2}{*}{$t$} & \multirow[b]{2}{*}{ Sig. } \\
\hline & & $B$ & Std. Error & & & \\
\hline \multirow[t]{2}{*}{1} & (Constant) & .386 & .174 & & 2.224 & .035 \\
\hline & perputaran piutang & .112 & .029 & .614 & 3.891 & .001 \\
\hline
\end{tabular}

Sumber: hasil olah data SPSS

Uji $\mathrm{t}$ ini dapat dilihat dari tingkat signifikansi dan hasil dari $\mathrm{t}$ hitung maupun $\mathrm{t}$ tabel. Jika hasil $t$ hitung lebih besar dari pada $t$ tabel maka ada pengaruh antara variabel perputaran piutang dengan return on investment, tetapi jika $t$ tabel lebih besar dari pada $t$ hitung berarti tidak terdapat pengaruh antar variabel. Berdasarkan tabel 6, tingkat signifikansi 0,001 dan $\mathrm{t}$ hitung diperoleh hasil 3,891. Sedangkan $\mathrm{t}$ tabel menunjukkan hasil 2,064. Hal ini menunjukkan bahwa t hitung lebih besar dari pada t tabel sehingga dapat ditarik kesimpulan Ho ditolak dan Ha diterima, jadi terdapat pengaruh antara perputaran piutang dengan return on investement yang signifikan Pada PT Telekomunikasi Persero Tbk. Hal ini sesuai dengan penelitian yang dilakukan (Santoso, 2013) dan (Luh Komang Suarnami, 2014) "Perputaran piutang berpengaruh secara signifikan terhadap profitabilitas". 


\section{KESIMPULAN}

Dari hasil pengujian hipotesa menunjukkan bahwa terdapat pengaruh signifikan Perputaran Piutang terhadap Return On Investment pada PT Tekomunikasi Persero Tbk. Pengaruh variabel independen (perputaran piutang) terhadap variabel dependen (return on investment) sebesar 3,77\% artinya variabel independen (perputaran piutang) hanya mempengaruhi variabel dependen (return on investment) sebesar $37,7 \%$ sedangkan sisanya $62,3 \%$ dipengaruhi oleh faktor lain

\section{DAFTAR PUSTAKA}

Harisson, W. T., Horngren, C. T., Thomas, C. W., \& Suwardy, T. (2012). Akuntansi Keuangan (Edisi IFRS) (jilid 1, Edisi 8). Jakarta: Erlangga.

Kasmir. (2013). Analisa Laporan Keuangan. Jakarta: Rajawali Pers.

Luh Komang Suarnami, I. W. (2014). Pengaruh Perputaran Piutang Dan Periode Pengumpulan Piutang Terhadap Profitabilitas Pada Perusahaan Pembiayaan. EJurnal Bisma Universitas Pendidikan Ganesha, jurusan Manajemen.

Manullang, M., \& Sinaga, D. (2005). Pengantar Manajemen Keuangan. Yogyakarta: Andi.

Munawir. (2007). Analisa Laporan Keuangan. Yogyakarta: Liberty.

Santoso, C. E. (2013). Perputaran Modal Kerja Dan Perputaran Piutang Pengaruhnya terhadap Profitabilitas Pada PT. Pegadaian (Persero) . Jurnal Emba: Jurnal riset Ekonomi, Bisnis, Manajemen Dan Akuntansi, 1581-1590.

Sarwono, J. (2006). Metode penelitian kuantitatif \& kualitatif. Yogyakarta: Graha Ilmu.

sugiyono. (2011). Metode Penelitian Kuantitatif kualitatif dan $R \&$ D. Bandung : Alfabeta.

Syamsudin, L. (2007). Manajemen keuangan perusahaan: konsep aplikasi dalam perencanaan, pengawasan dan pengambilan keputusan. Jakarta: Raja Grafindo Persada.

Wiratna Sujarweni, V. (2016). Kupas tuntas penelitian akuntansi dengan SPSS. Pustaka Baru Press: Yogyakarta.

Yuliani, R., \& Salim, U. (2012). Pengaruh Perputaran Piutang Terhadap Profitabilitas Pada Perusahaan PT. Unilever Indonesia Tbk Tahun 2005-2012. Jurnal Ilmiah Mahasiswa FEB Universitas Brawijaya, -. 